\title{
Regulation of phosphatidylinositol-phosphate kinase II $\gamma$ gene transcription by thyroid-stimulating hormone in thyroid cells
}

\section{S Park, W Lee, K H You, H Kim ${ }^{1}$, J M Suh ${ }^{1}$, H K Chung ${ }^{1}$, M Shong ${ }^{1}$ and $\mathbf{O}$ Y Kwon ${ }^{2}$}

\author{
Department of Biology, College of Natural Sciences, Chungnam National University, Taejon 305-764, \\ Korea \\ ${ }^{1}$ Department of Internal Medicine, College of Medicine, Chungnam National University, \\ Taejon 301-040, Korea \\ ${ }^{2}$ Department of Anatomy, College of Medicine, Chungnam National University, Taejon 301-131, Korea
}

(Requests for offprints should be addressed to O Y Kwon; Email: oykwon@cnu.ac.kr)

\begin{abstract}
This study was performed to evaluate the effects of thyroid-stimulating hormone (TSH) on phosphatidylinositol-4-phosphate 5-kinase type II $\gamma$ (PIPKII $\gamma$ ) gene expression in the thyrocytes of FRTL-5 cells. Although PIPKII $\gamma$ mRNA was expressed constantly in the absence of added TSH, its expression increased remarkably in the presence of $10^{-9} \mathrm{M}$ TSH. This increase started within $6 \mathrm{~h}$ of the addition of TSH, and reached a maximum at $8 \mathrm{~h}$. The mRNA expression properties of PIPKII $\gamma$ in the cells were identified using inhibitors. Actinomycin D blocked PIPKII $\gamma$ transcription strongly, while cycloheximide did not. In an experiment using 5,6-dichlo-1- $\beta$-D-ribofuranosyl-
\end{abstract}

benzimidaxole, the half-life of PIPKII $\gamma$ mRNA was approximately $6 \mathrm{~h}$ in the presence or absence of TSH, and it was not affected by the stability of the PIPKII $\gamma$ mRNA. The effects of TSH on PIPKII $\gamma$ gene expression were specific, and other growth factors examined (transferrin, insulin and hydrocortisone) did not alter its expression. It is possible that the mechanism of PIPKII $\gamma$ gene expression is involved in the permissive effect of the TSH-cAMP cascade proper. Our results indicate, for the first time, that the expression of PIPKII $\gamma$ is regulated transcriptionally by TSH in thyrocytes.

Fournal of Molecular Endocrinology (2001) 26, 127-133

\section{INTRODUCTION}

Phosphoinositols (PtdIns) are found in all eukaryotes, and constitute $2-8 \%$ of the total cellular phospholipids that induce physiological responses, ranging from survival, growth, differentiation, cytoskeletal organization and vesicular secretion (Shibasaki et al. 1997, Toker 1998, Corvera et al. 1999). PtdIns kinases (PIPKs) are classified into two major subtypes (types I and II) on the basis of their chromatographic profiles and biochemical features. Each is comprised of three isoforms ( $\mathrm{I} \alpha$, I $\beta$, I $\gamma$ and II $\alpha$, II $\beta$ and II $\gamma$ ) (Ishihara et al. 1996, Loijens \& Anderson 1996, Hinchliffe et al. 1998, Anderson et al. 1999), and it is believed that each has its own specific role.

The type I isozyme is activated by phosphatidic acid (Jenkins et al. 1994), which binds to the small
GTPase, Rho and Rac (Tolias et al. 1995, Ren et al. 1996). This stimulation may be essential for the resynthesis of phosphatidylinositol 4,5bisphosphate in response to phosphatidylinositol 4,5-bisphosphate hydrolysis by phosphatidic C, and the subsequent conversion of 1,2-diacylglycerol to phosphatidic acid (Nishikawa et al. 1998). Type I is also involved in $\mathrm{Ca}^{2+}$-dependent exocytosis and neurotransmitter release (Hay et al. 1995). In the fruit fly, Drosophila melanogaster, type I is required for cell viability, germline development, and the proper structural development of sensory bristles (Hassen et al. 1998). While type I is stimulated by both heparin and spermine, type II is inhibited by heparin, and either inhibited or not affected by spermine, which specifically binds to the receptor of p55 tumor necrosis factor (TNF) receptor, located in the cytoplasmic region, and which is regulated by 
TNF- $\alpha$ (Castellino et al. 1997). To date, the known biological function of the type II isozyme is much more limited than that of type I.

Phosphatidylinositol-4-phosphate 5-kinase type II $\gamma$ (PIPKII $\gamma$ ) was recently isolated from rat fibroblasts as a novel PtdIns(4)P 5-kinase isozyme with 420 amino acids and $47048 \mathrm{Da}$, and showed a higher homology to the type II $\alpha$ and II $\beta$ isoforms (61.1\% and $63.7 \%$ amino acid identities respectively) of PIPKII than to the type I isoforms. Unlike the PIPKII $\alpha$ and II $\beta$ isoforms, PIPKII $\gamma$ is specifically localized in the endoplasmic reticulum (ER), where phosphorylation occurs through several stimuli such as serum, epidermal growth factor and platelet-derived growth factor (Itoh et al. 1998). In previous studies, we have isolated thyroidstimulating hormone (TSH)-dependently expressed genes, using a differential display-PCR method, from rat thyroid FRTL-5 cells. The results of the partial DNA sequencing demonstrated that one of these was a PIPKII $\gamma$ DNA fragment (Shong et al. 1999).

At present, the effects of TSH on PIPKII $\gamma$ gene expression are still unclear. With this in mind, we have investigated the mRNA expression of PIPKII $\gamma$ in terms of the cellular response to TSH by Northern blot analysis, and have used actinomycin D (a transcription inhibitor), cycloheximide (another translation inhibitor), 5,6-dichlo-1- $\beta$-Dribofuranosylbenzimidaxole (DRB; a RNA polymerase II inhibitor) and growth factors (insulin, transferrin and hydrocortisone) to investigate the mRNA expression of PIPKII $\gamma$ in thyrocytes. The results of our study show that TSH dose- and time-dependently controls PIPKII $\gamma$ gene expression at the transcription level in thyrocytes, and that the expression of PIPKII $\gamma$ may be involved in the intracellular cAMP signal pathway.

\section{MATERIALS AND METHODS}

\section{Materials}

Highly purified bovine TSH was obtained either from the hormone distribution program of the National Institute of Diabetes and Digestive and Kidney Diseases, National Institutes of Health (NIDDK-bTSH I-1; $30 \mathrm{U} / \mathrm{mg} ;$ Bethesda, MD, USA) or from a previously described preparation (Kohn et al. 1995) $(26 \pm 3 \mathrm{U} / \mathrm{mg})$ homogeneous in the ultracentrifuge, with a molecular weight of about 27500 with the amino acid and carbohydrate composition of TSH. The $\left[{ }^{32} \mathrm{P}\right] \mathrm{dATP} \quad(3000$ $\mathrm{Ci} / \mathrm{mmol}$ ) was from DuPont-New England Nuclear (Boston, MA, USA), and all other materials used in
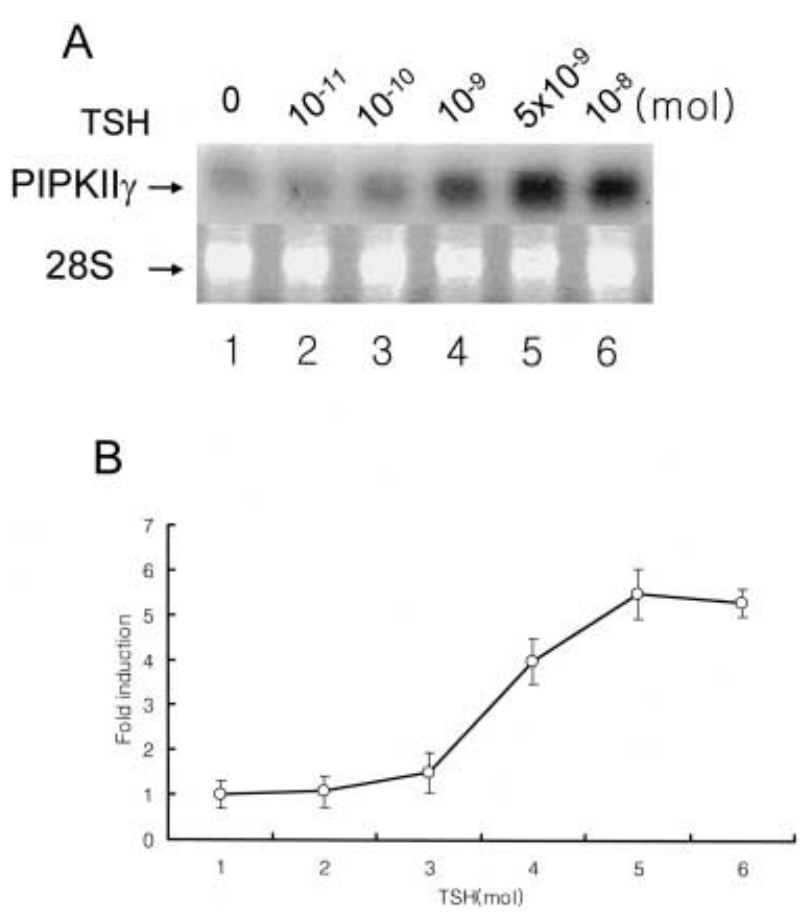

FIGURE 1. TSH enhancement of the PIPKII $\gamma$ mRNA. Confluent FRTL-5 cells were treated with the indicated doses of TSH at $37^{\circ} \mathrm{C}$ for $24 \mathrm{~h}$, and after $48 \mathrm{~h}$ of culture without any hormones added to the growth medium. Total RNA was isolated as described in Materials and Methods and subjected to Northern blotting. An arrow indicates PIPKII $\gamma$ (upper panel of A), and ethidium bromide staining of $28 \mathrm{~S}$ ribosomal RNA (lower panel of A) was used to indicate the equivalence of gel loading. (B) The results of quantification by phosphorimaging. Values represent the means $(n=3) \pm$ S.D.

this study were obtained from Sigma Chemical Co. (St Louis, MO, USA) unless noted otherwise.

\section{Cell culture}

The rat thyroid cell line FRTL-5 (American Type Culture Collection, Rockville, MD, USA; CRL no. 8305) was cultured in Coon's medium containing $5 \%$ calf serum and $10^{-9} \mathrm{M}$ TSH, $5 \mu \mathrm{g} / \mathrm{ml}$ transferrin, $1 \mu \mathrm{g} / \mathrm{ml}$ insulin and $10 \mathrm{nM}$ hydrocortisone at $37^{\circ} \mathrm{C}$ and under $5 \% \mathrm{CO}_{2}$ conditions until confluent. Their doubling time with TSH was $36 \pm 6 \mathrm{~h}$, and they did not proliferate without TSH. The cells were diploid between the 5 th and 20th passage. Fresh medium was added to the cells every 2 or 3 days and cells were passaged every 2 weeks. As a separate experiment, cells were washed three times with cold phosphate-buffered saline to remove 
A

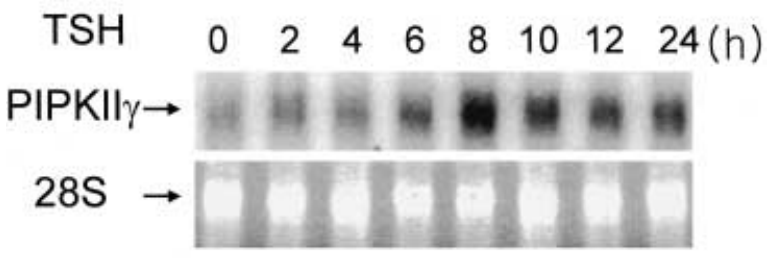

B

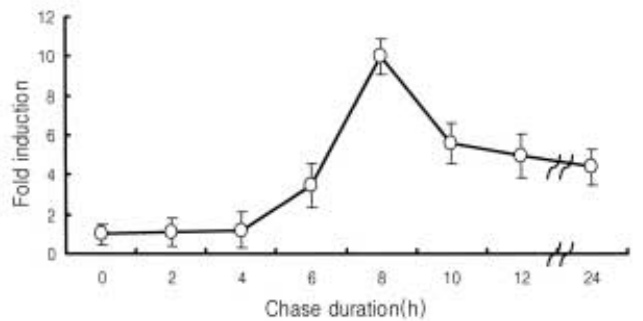

FIGURE 2. Time-course of the effects of TSH on PIPKII $\gamma$ mRNA. Confluent FRTL-5 cells were cultured for the indicated periods of time in the absence $(-)$ and presence $(+)$ of $10^{-9} \mathrm{M} \mathrm{TSH}$, after $48 \mathrm{~h}$ of culture without any hormones in the growth medium. Total RNA was isolated as described in Materials and Methods and subjected to Northern blotting. An arrow indicates PIPKII $\gamma$ (upper panel of A), and ethidium bromide staining of the $28 \mathrm{~S}$ ribosomal RNA (lower panel of A) was used to indicate the equivalence of gel loading. (B) The results of quantification by phosphorimaging. Data represent means \pm S.D. of three values per treatment.

the hormones completely and then incubated for $48 \mathrm{~h}$ without hormones in the growth medium.

\section{RNA isolation and Northern blot analysis}

After being incubated at various TSH concentrations, for different times and with other treatments, the collected cells were transferred into a sterile microtube and the total RNA of each sample was isolated using a RNAzol Kit (Tel-Test, Inc., Friendswood, TX, USA) according to the manufacturer's instructions. The total RNA pellets were suspended in diethylprocarbonate-treated water, and the yield was determined twice for each sample using a UV spectrophotometer. The mRNA expression level of PIPKII $\gamma$ (GenBank no. AF030558) was analyzed by Northern blotting (Itoh et al. 1998). Equal amounts of RNA $(20 \mu \mathrm{g})$ were

www.endocrinology.org separated on a denaturing agarose gel $(2 \cdot 5 \%$ agarose containing $2 \cdot 2 \mathrm{M}$ formaldehyde) and transferred to a nylon membrane (Boehringer Mannheim $\mathrm{GmbH}$, Mannheim, Germany). After the filter was UVcrosslinked (UV-stratalinker 1800; Stratagene, La Jolla, CA, USA) it was prehybridized in a high SDS buffer ( $7 \%$ SDS, $50 \%$ formamide, $5 \times \mathrm{SSC}, 2 \%$ blocking reagent, $50 \mathrm{mM}$ sodium phosphate) at $50{ }^{\circ} \mathrm{C}$ for $2 \mathrm{~h}$. This hybridization was performed with the same SDS buffer containing $\left[{ }^{32} \mathrm{P}\right] \mathrm{dATP}$ labeled PIPKII $\gamma$ DNA fragments at $50{ }^{\circ} \mathrm{C}$ overnight. The nylon membrane was rinsed twice with $2 \times \mathrm{SSC}$ and $0 \cdot 1 \% \mathrm{SDS}$ at room temperature, and then exposed to an X-ray film in a deep-freeze for 5-24 h to allow the mRNA signals to develop. The PIPKII $\gamma$ DNA fragments were isolated from the agarose gel using a silica-based matrix of the DNA PreMate Kit (Bioneer, Korea), radiolabeled using the random primer method with a kit (Amersham Life Science, Arlington Heights, IL, USA), and used as molecular probes for the Northern blot analysis. A phosphorimaging analyzer (400B; Molecular Dynamics, Boston, NJ, USA) was used to measure the hybridization signals.

\section{RESULTS AND DISCUSSION}

We determined whether the PIPKII $\gamma$ gene was activated in the thyrocytes of FRTL-5 cells by stimulating the TSH. The cells were incubated in a control growth medium with only $5 \%$ calf serum and without TSH, transferrin, insulin or hydrocortisone (called $4 \mathrm{H}$ ) for 2 days so as to completely remove the hormonal effect. Various concentrations of TSH were then added to the growth media and cultured for $24 \mathrm{~h}$. The resulting total RNA were subjected to Northern blot analysis. As shown in Fig. 1, PIPKII $\gamma$ mRNA was expressed constantly at all levels in the absence of TSH (control) and its expression increased in line with the TSH concentration. When $10^{-9} \mathrm{M}$ TSH was added, a remarkable expression was induced in the FRTL-5 cells and this reached a maximum at $5 \times 10^{-9} \mathrm{M}$; increasing TSH concentrations further to $10^{-8} \mathrm{M}$ decreased this expression. This is the first time that TSH has been shown to increase the mRNA level of PIPKII $\gamma$ in thyrocytes. When one considers the fact that the PIPKII $\gamma$ gene was expressed at all levels in the absence of TSH in thyrocytes, it is suggested that PIPKII $\gamma$ mRNA expression is required under normal cell conditions, and that its expression enhanced TSH in response to the altered intracellular conditions.

Next, we examined the effects of TSH on PIPKII $\gamma$ mRNA expression over time during a 


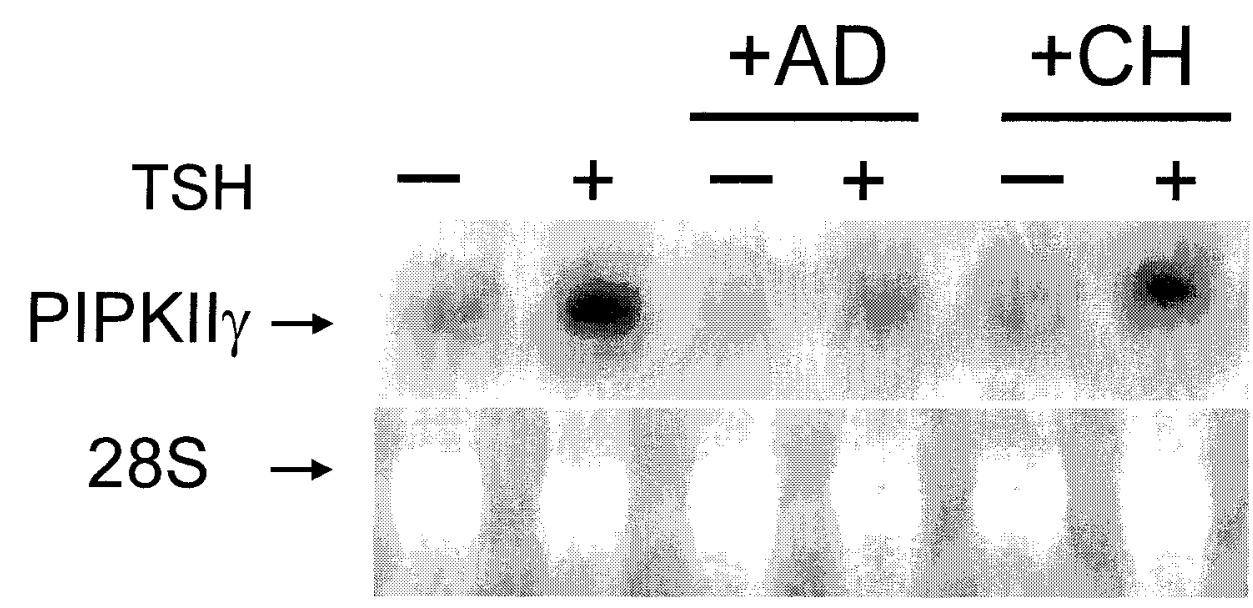

FIGURE 3. Effects of actinomycin D and cycloheximide on TSH-induced accumulation of PIPKII $\gamma$ mRNA. Confluent FRTL-5 cells were treated with $(+)$ or without $(-)$ $10^{-9} \mathrm{M}$ TSH for $24 \mathrm{~h}$ in the presence or absence of $0 \cdot 2 \mu \mathrm{g} / \mathrm{ml}$ actinomycin D (AD) or $2 \mu \mathrm{g} / \mathrm{ml}$ cycloheximide $(\mathrm{CH})$, after $48 \mathrm{~h}$ of culture without any additional hormones in the growth medium. Total RNA was isolated as described in Materials and Methods and subjected to Northern blotting. An arrow indicates PIPKII $\gamma$ (upper panel), and ethidium bromide staining of the $28 \mathrm{~S}$ ribosomal RNA (lower panel) was used to indicate the equivalence of gel loading. The experiment was performed three times with similar results.

24-h exposure. FRTL-5 cells were incubated for the number of hours indicated in the presence of $10^{-9}$ M TSH, after preincubation for 2 days in growth medium with $5 \%$ calf serum and without 4H. Although PIPKII $\gamma$ signal expression was detected when the cells were not chased, it increased gradually with chase periods for $24 \mathrm{~h}$ in $10^{-9} \mathrm{M}$ TSH (Fig. 2). PIPKII $\gamma$ mRNA increased time dependently and peaked at $8 \mathrm{~h}$, at approximately nine times its baseline value, and then gradually decreased.

To investigate the mode of TSH action on the regulation of PIPKII $\gamma$ gene expression, FRTL-5 cells were treated for $24 \mathrm{~h}$ with actinomycin D and cycloheximide in the presence or absence of $10^{-9} \mathrm{M}$ TSH after preincubation for 2 days in growth medium with $5 \%$ calf serum and without $4 \mathrm{H}$. The Northern blotting results are shown in Fig. 3. As has already been shown in Figs 1 and 2, TSH alone fully increased PIPKII $\gamma$ mRNA expression in FRTL-5 cells. When the cells were treated with $0 \cdot 2 \mu \mathrm{g} / \mathrm{ml}$ actinomycin $\mathrm{D}$ in the presence or absence of TSH, the resulting signal of the PIPKII $\gamma$ mRNA almost vanished whether TSH was present or not. On the other hand, for the cells treated with $2 \mu \mathrm{g} / \mathrm{ml}$ cycloheximide in the presence or absence of TSH, the expression pattern of PIPKII $\gamma$ was similar to that of the control, although its expression was slightly weaker. This weakness was due to the activation of the pre-existing PIPKII $\gamma$ mRNAs, which had already become aggravated before the actinomycin $\mathrm{D}$ treatment. These results suggest that PIPKII $\gamma$ expression is completely regulated at the transcriptional level but not at the translational/ post-transcriptional regulation levels in thyrocytes. Although TSH alone fully enhanced PIPKII $\gamma$ expression, TSH promoted only one expression pathway for the transcriptional up- or downregulation of PIPKII $\gamma$, as shown in Fig. 3. If TSH had taken one of the alternative pathways for PIPKII $\gamma$ expression, some strong signal should have been evident when cells were treated with TSH plus actinomycin D or plus cycloheximide.

We demonstrated the effects of TSH on the stability of PIPKII $\gamma$ mRNA using $25 \mu \mathrm{g} / \mathrm{ml} \mathrm{DRB}$, a specific inhibitor of RNA polymerase II, by determining its half-life in both the presence and absence of TSH. DRB treatment is known to prevent mRNA synthesis and permits the intracellular residue mRNAs to be monitored (Primorac et al. 1999). As is shown in Fig. 4, no signals were commonly detected in either the presence or absence of TSH after $8 \mathrm{~h}$ of treatment with DRB in FRTL-5 cells. This means that the previously aggravated PIPKII $\gamma$ mRNA had almost decayed, as the amount of PIPKII $\gamma$ mRNA became aggravated just by being treated with DRB. The half-life of PIPKII $\gamma$ mRNA in the FRTL-5 cells was approximately $6 \mathrm{~h}$ in the absence or presence of TSH. 
A $+\mathrm{TSH}$

B

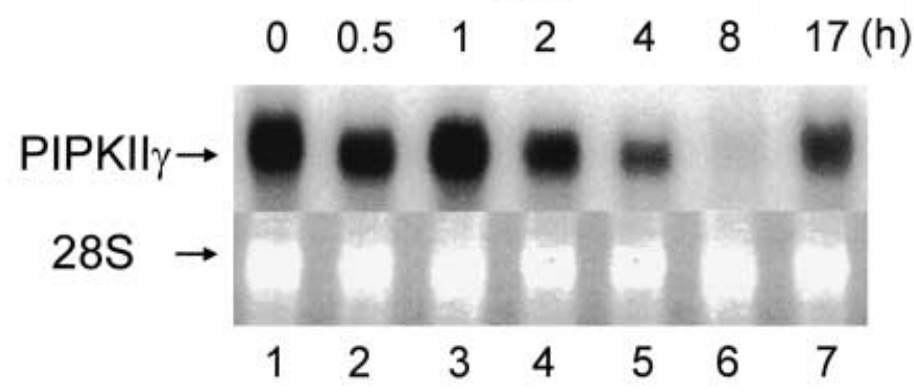

$-\mathrm{TSH}$
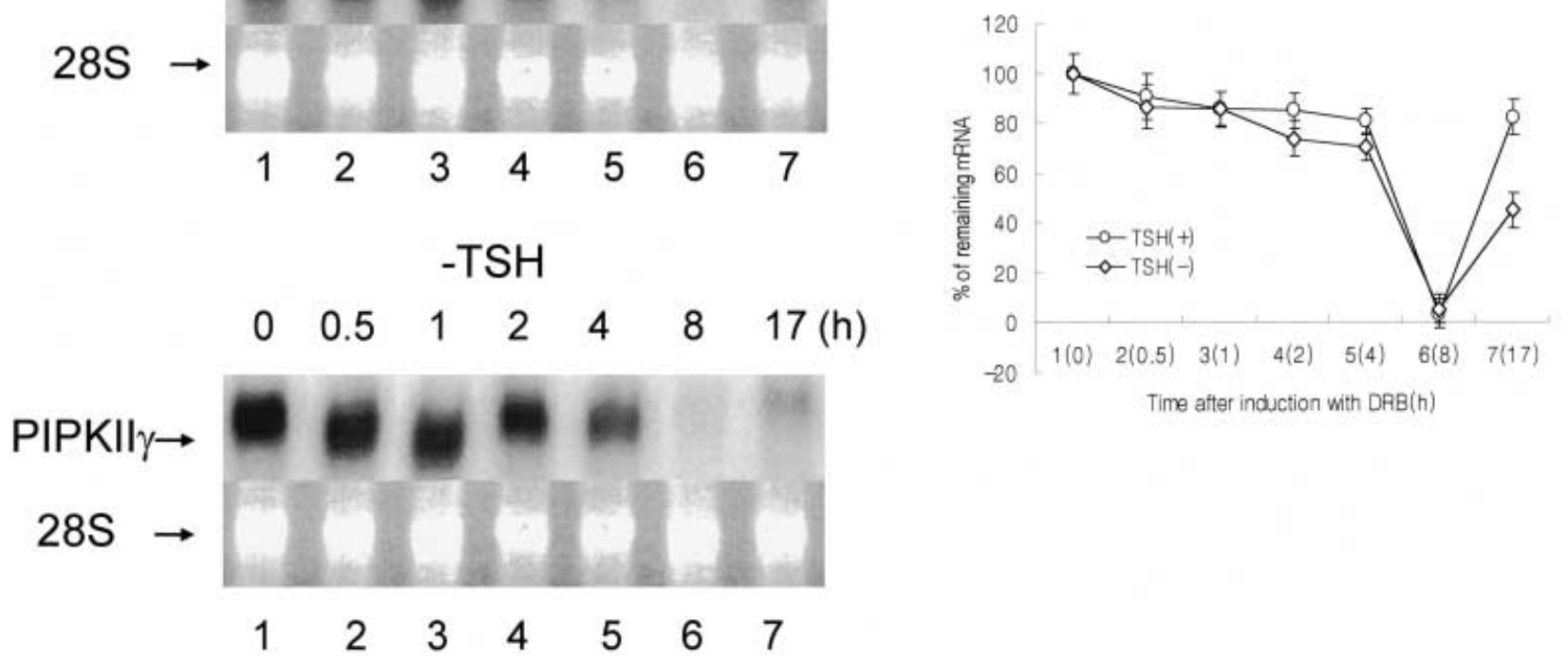

FIGURE 4. Effect of TSH on the stability of PIPKII $\gamma$ mRNA in FRTL5 cells. Confluent FRTL-5 cells were treated with the indicated doses of $\mathrm{TSH}$ at $37^{\circ} \mathrm{C}$ for $24 \mathrm{~h}$, after culturing for $48 \mathrm{~h}$ without any hormones added to the growth medium. DRB $(25 \mu \mathrm{g} / \mathrm{ml})$ was added to medium $30 \mathrm{~min}$ before adding the vehicle ( -$)$ or $10^{-9} \mathrm{M} \mathrm{TSH}(+)$. Total RNA was isolated at various times after adding the vehicle or TSH, as described in Materials and Methods, and subjected to Northern blotting. An arrow indicates PIPKII $\gamma$, and ethidium bromide staining of the $28 \mathrm{~S}$ ribosomal RNA was used to indicate the equivalence of gel loading. (B) The quantified results of (A). Values represent the means $(n=3) \pm$ S.D.

By examining graphically the results of the DRB experiment, it was apparent that there was no serious difference between the control and TSHtreated groups, which implied that the stability of PIPKII $\gamma$ mRNA was not largely affected by either the presence or absence of TSH in FRTL-5 cells. In other words, TSH is not involved in the post-transcriptional steps, and is effective only in the gene expression step. In addition, both signals seemed to be enhanced after $17 \mathrm{~h}$ of DRB treatment because of the inactivating effect of DRB, which had already been added by a single term of incubation at $37^{\circ} \mathrm{C}$, and because the signal appeared stronger when TSH was present than when TSH was absent.

We examined the effects of growth factors (e.g. transferrin, insulin and hydrocortisone, which are essential for growing FRTL-5 culture cells) on PIPKII $\gamma$ gene regulation in the presence and absence of TSH. The cells were treated for $24 \mathrm{~h}$ with $5 \mu \mathrm{g} / \mathrm{ml}$ transferrin, $1 \mu \mathrm{g} / \mathrm{ml}$ insulin or $10 \mathrm{nM}$ hydrocortisone, in the presence or absence of
$10^{-9} \mathrm{M}$ TSH after preincubation for $24 \mathrm{~h}$ in the growth media with $5 \%$ calf serum and without $4 \mathrm{H}$.

As shown in Fig. 5, transferrin, insulin and hydrocortisone did not affect the level of PIPKII $\gamma$ mRNA in FRTL-5 cells remarkably, in either the presence or the absence of TSH. When TSH was added together with the growth factors, PIPKII $\gamma$ expression was not additive, and TSH alone was largely responsible for the increased PIPKII $\gamma$ mRNA levels. This shows that TSH specifically affects PIPKII $\gamma$ expression, at least in FRTL-5 cells, while the growth factors transferrin, insulin and hydrocortisone play an important role in the growth of FRTL-5 cells. If the growth factors had affected PIPKII $\gamma$ expression, some strong signals should have been evident when the cells were treated with a combination of TSH, transferrin, insulin or hydrocortisone. However, as shown in Fig. 5, no strong signals were found when the cells were treated with additional growth factors, compared with the signal produced by treatment with TSH. 


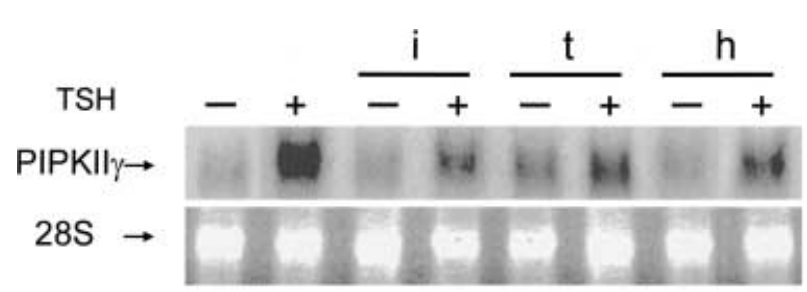

FIGURE 5. Specificity of the the effect of TSH on the enhancement of PIPKII $\gamma$ mRNA. Confluent FRTL-5 cells were treated for $24 \mathrm{~h}$ with $(+)$ or without $(-)$ $10^{-9} \mathrm{M} \mathrm{TSH}$ in the presence of transferrin $(\mathrm{t} ; 5 \mu \mathrm{g} / \mathrm{ml})$, insulin $(\mathrm{i} ; 1 \mu \mathrm{g} / \mathrm{ml})$ or $10 \mathrm{nM}$ hydrocortisone $(\mathrm{h})$, after culturing for $48 \mathrm{~h}$ without any hormones in the growth medium. Total RNA was isolated as described in Materials and Methods and subjected to Northern blotting. An arrow indicates PIPKII $\gamma$ (upper panel), and ethidium bromide staining of the $28 \mathrm{~S}$ ribosomal RNA (lower panel) was used to indicate the equivalence of gel loading. The experiment was performed three times with similar results.

It is not yet fully understood why a TSH stimulatory signal is involved in the intracellular cascade pathway for PIPKII $\gamma$ expression. TSH actions were mimicked by forskolin (enhancer of intracellular cAMP), which confirmed that the cAMP cascade mediated its expression in FRTL-5 cells, and stimulated DNA synthesis and proliferation (Van Sande et al. 1989, Dremier et al. 1997). To confirm PIPKII $\gamma$ expression when the thyrocytes were treated with forskolin, approximately the same PIPKII $\gamma$ expression was detected with both the TSH and the forskolin treatments (Fig. 6). The results shown in Fig. 6 suggest that forskolin is one of the transcription factors in the expression of the PIPKII $\gamma$ gene in thyrocytes. We also hypothesize that TSH stimulates the concentration of intracellular cAMP which, in turn, triggers other intracellular factors associated with PIPKII $\gamma$ gene transcription.

Considering that the PIPKII $\gamma$ mRNA was constantly expressed in the cells that were not treated with TSH, and bearing in mind the results of previous reports, PIPKII $\gamma$ would seem to act as a kinase to produce both phosphatidylinositol 4-bisphosphate and phosphatidylinositol 4,5bisphosphate (Anderson et al. 1999). In addition, the results of our study demonstrated that TSH strictly controls PIPKII $\gamma$ gene expression at the transcriptional level in thyrocytes. It was suggested by Itoh et al. (1998) that each subfamily of PIPK has a distinct localization and function. It is interesting that PIPKII $\gamma$ is specifically localized in the ER (Helms et al. 1991, Wong et al. 1997), although most PIPK activity is detected in the plasma membrane and the cytosol, where the phosphorylated form of PIPKII $\gamma$ was detected in
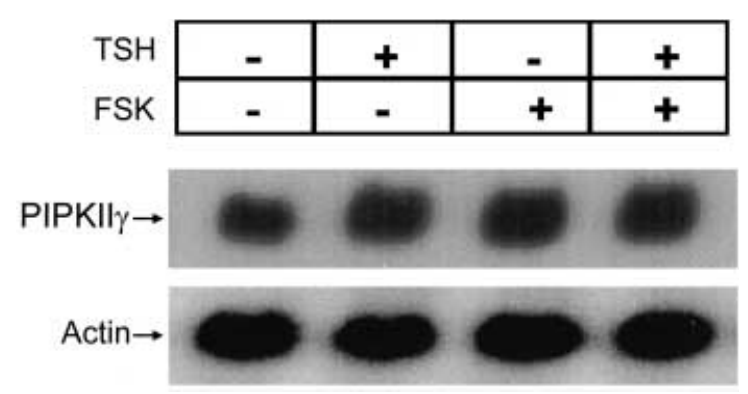

FIGURE 6. Effects of TSH on PIPKII $\gamma$ gene expression. Confluent FRTL-5 cells were treated for $6 \mathrm{~h}$ either with (+) or without $(-) 10^{-9} \mathrm{M}$ TSH and $10 \mathrm{nM}$ forskolin (FSK) and/or combined with TSH+FSK in the growth medium. Total RNA was isolated as described in Materials and Methods and subjected to Northern blotting. The experiment was performed three times with similar results.

response to extracellular stimuli (e.g. growth factors or hormones) and binds to one of the ER resident molecular chaperones of immunoglobulin-binding protein (Bip) (Itoh et al. 1998). Binding with Bip makes it possible for phosphorylated PIPKII $\gamma$, induced by stimulation, to be involved in the post-translational step of protein folding and the assembly of newly synthesized proteins in the ER as distinct functions in vivo. Further studies are necessary to clarify the roles of PIPKII $\gamma$ as an ER chaperone in thyrocytes, where it might participate in the folding and assembly of thyroglobulin, the major thyroid secretory glycoprotein.

\section{ACKNOWLEDGEMENT}

This research was supported by Korea Research Foundation Grant (KRF-2000-015-FP0017).

\section{REFERENCES}

Anderson RA, Boronenkov IV, Doughman SD, Kunz J \& Loijens JC 1999 Phosphatidylinositol phosphate kinases, a multifaced family of signaling enzymes. Fournal of Biological Chemistry 274 9907-9910.

Castellino AM, Parker GJ, Boronenkov IV, Anderson RA \& Chao MV 1997 A novel interaction between the juxtamembrane region of the p55 tumor necrosis factor receptor and phosphatidylinositol-4-phosphate 5-kinase. Fournal of Biological Chemistry 272 5861-5870.

Corvera S, D’Arrigo A \& Stenmark H 1999 Phosphoinositides in membrane traffic. Current Opinion in Cell Biology 11 460-465.

Dremier S, Pohl V, Poteet-Smith C, Roger PP, Corbin J, Doskeland SO, Dumont JE \& Maenhaut C 1997 Activation of cyclic AMP-dependent kinase is required but may not be sufficient to mimic cyclic AMP-dependent DNA synthesis 
and thyroglobulin expression in dog thyroid cells. Molecular and Cellular Biology 17 6717-6726.

Hassen BA, Prokopenko SN, Breuer S, Zhang B, Paululat A \& Bellen HHJ 1998 Skittles, a drosophila phosphatidylinositol4-phosphate 5-kinase, is required for cell viability, germline development and bristle morphology, but not for neurotransmitter release. Genetics 150 1527-1537.

Hay JC, Fisette PL, Jenkins GH, Fukami K, Takenawa T, Anderson RA \& Martin TF 1995 ATP-dependent inositide phosphorylation required for $\mathrm{Ca}\left({ }^{2+}\right)$-activated secretion. Nature 374 173-177.

Helms JB, de Vries KJ \& Wirtz KW 1991 Synthesis of phosphatidylinositol 4,5-bisphosphate in the endoplasmic reticulum of Chinese hamster ovary cells. Fournal of Biological Chemistry 266 21368-21374.

Hinchliffe KA, Irvine RF \& Divecha N 1998 Regulation of ptdIns4p 5-kinase $\mathrm{C}$ by thrombin-stimulated changes in its phosphorylation state in human platelets. Biochemical fournal 329 115-119.

Ishihara H, Shibasaki Y, Kizuki N, Katagiri H, Yazaki Y, Asano T \& Oka Y 1996 Cloning of cDNAs encoding two isoforms of $68-\mathrm{kDa}$ type I phosphatidylinositol4-phosphate 5-kinase. Fournal of Biological Chemistry 271 23611-23614.

Itoh T, Ijuin T \& Takenawa T 1998 A novel phosphatidylinositol-5-phosphate 4-kinase (phosphatidylinositol-phosphate kinase II) is phosphorylated in the endoplasmic reticulum in response to mitogenic signals. Fournal of Biological Chemistry 273 20292-20299.

Jenkins GH, Fisette PL \& Anderson RA 1994 Type I phosphatidylinositol 4-phosphate 5-kinase isoforms are specifically stimulated by phosphatidic acid. Fournal of Biological Chemistry 269 11547-11554.

Kohn LD, Shimura H, Shimura Y, Hidaka A, Giuliani C, Napolitano G, Ohmori M, Laglia G \& Saji M 1995 The thyrotropin receptor. Vitamins and Hormone 50 287-384.

Loijens JC \& Anderson RA 1996 Type I phosphatidylinositol-4-phosphate 5-kinases are distinct members of this novel lipid kinase family. Fournal of Biological Chemistry 271 32937-32943.
Nishikawa K, Toker A, Wong K, Marignani PA, Johannes F \& Cantley LC 1998 Association of protein kinase C with type II phosphatidylinositol 4-kinase and type I phosphatidylinositol-4-phosphate 5-kinase. Fournal of Biological Chemistry 273 23126-23133.

Primorac D, Johnson CV, Lawrence JB, McKinstry MB, Stover ML, Schanfield MS, Andjelinovic S, Tadic T \& Rowe DW 1999 Premature termination codon in the aggrecan gene of nanomelia and its influence on mRNA transport and stability. Croatin Medical Fournal 40 528-532.

Ren XD, Bokoch GM, Traynor-Kaplan A, Jenkins GH, Anderson RA \& Schwartz MA 1996 Physical association of the small GTPase Rho with a $68-\mathrm{kDa}$ phosphatidylinositol 4-phosphate 5-kinase in Swiss 3T3 cells. Molecular Biology of the Cell 7 435-442.

Shibasaki Y, Ishihara H, Kizuki N, Asano T, Oka Y \& Yazaki Y 1997 Massive actin polymerization induced by phosphatidylinositol-4-phosphate 5-kinase in vivo. Fournal of Biological Chemistry 272 7578-7581.

Shong M, Kim YJ, Choi Y \& Kwon OY 1999 Identification of genes in a thyroid-stimulating hormone (TSH). Zeitschrift für Naturforschung 54c 578-582.

Toker A 1998 The synthesis and cellular roles of phosphatidylinositol 4,5-bisphosphate. Current Opinion in Cell Biology 10 254-261.

Tolias KF, Cantley LC \& Carpenter CL 1995 Rho family GTPases bind to phosphoinositide kinases. Fournal of Biological Chemistry 270 17656-17659.

Van Sande J, Lefort A, Beebe S, Roger P, Perret J, Corbin J \& Dumont JE 1989 Pairs of cyclic AMP analogs, that are specifically synergistic for type I and type II cAMPdependent protein kinases, mimic thyrotropin effects on the function, differentiation expression and mitogenesis of dog thyroid cells. European Fournal of Biochemistry 183 699-708.

Wong K, Meyers R \& Cantley LC 1997 Subcellular locations of phosphatidylinositol 4-kinase isoforms. Fournal of Biological Chemistry 272 13236-13241.

RECEIVED 4 September 2000 ACCEPTED 20 October 2000 